\title{
Swedish minister rebuilds scientists' trust
}

[sTOCKHOLm] Sweden's new science minister, Thomas Östros, is moving to strengthen links with the science community that had been severely strained during the tenure of his predecessor, Carl Tham.

At a press conference in Stockholm last week, Östros confirmed that he would not be making any further changes to the management of the Swedish Foundation for Strategic Research, which Tham had wanted to be run entirely by politicians.

Östros also announced that government funding for research would increase by five per cent next year. And he confirmed that his government was keen to support curiositydriven research based on an agenda set by the scientific community.

The decision on the research foundation ends more than 20 years of conflict. Östros' first peace offering was the presentation of a gold medal, Illis Quorum - for outstanding achievements in the arts and sciences - to Ingvar Lindgren, the outgoing executive managing director of the foundation, at a recent seminar to celebrate the foundation's fifth anniversary.

Together with two other 'strategic foundations', it had been created in the early 1990s by the then conservative government, using money from a fund that had been set up to give employees a share of companies' wealth.

At his first press conference in 1994, Tham had said that his top priority was to change the statutes of these foundations and to place all their funds under direct political control. But Östros said at the anniversary seminar that he was happy to leave the current arrangements as they were.

The dispute has its origins in the 1970s. The Swedish Labour Organisation suggested that a Workers' Fund - controlled by the trade unions - should be set up out of a tax on the profits of private companies, and the money used to buy shares in the companies for the benefit of employees.

The fund, strongly supported by leftwing political parties, was finally set up in a modified form in 1984. But when the conservatives came to power in 1990, they took the money and used it to create a number of independent, private research foundations (see Nature 360, 512; 1992).

The foundations were run by independent experts, and board members appointed their own successors. The conservatives moved more than SKr10 billion (US\$1.2 billion) out of the public domain into the private sphere this way.

After the social democrats regained power in 1994, Tham tried to change the status of the foundations and make their money public again. He failed, but succeeded in changing the composition of their boards and the way they were recruited. They now consist of a mixture of scientific experts and politicians, all appointed by the government.

A public investigation set up by Tham proposed that the boards should consist solely of members of parliament. This was widely opposed by the research community.

Östros's statements suggest that there will be no more changes in the way the foundations are run. At his press conference last week, he repeated his wish to strengthen the dialogue with the scientific community. $\mathrm{He}$ confirmed that he regards the controversy around the strategic foundations as settled.

"We now regard the foundations as a belonging to the family of public agencies for funding science," he said, adding that he thinks the foundations are a valuable new way of financing science.

Only SKr 15 billion of the country's SKr58 billion science funding comes directly from the government - the rest is from industry, the military and the strategic foundations. A five per cent increase in government funding will give science an extra SKr779 million by the year 2002. The money will be used to strengthen basic research and education within the technical and natural sciences.

Though this looks like a minor increase, it is a remarkable shift of focus from applied to basic research. It has been welcomed by scientists who were critical of a public-funding policy that favoured applied research.

In presenting the bill, the minister said he was confident that curiosity-driven basic research was the best guarantee of quality in science, and the most effective way of obtaining useful knowledge and commercially successful applications in the long term.
Östros said that the bill should be seen as a first step towards a fundamental reassessment of Swedish science policy which would produce a more long-term strategy, to be presented in a bill in 2000 .

Swedish science councils, authorities, universities and organizations will be commissioned to work out research strategies of their own, and to look at the needs of developing Swedish science. The research councils will also be instructed to hold a series of conferences to gain background material for the newbill.

The public consultation that preceded Östros's bill suggested that all public funding agencies should be reorganized into four big research councils. But this suggestion met with strong protests from representatives of applied research.

Östros says he agrees on the need for a more effective way of distributing public money to science, but feels that the issue needs more investigation. No imminent change in the organization of the research councils is planned.

Östros has gained considerable backing from the scientific community during his seven months in office. One reason is his choice of members of the government's science advisory board. In addition to representatives from leading scientific institutions, the board includes officials from export- and research-dependent industries, as well as science students.

The appointment of immunologist Hans Wigzell from the Karolinska Institute as a personal science adviser to the government has also been widely welcomed. PeterSylwan

\section{Mars sundial celebrates joy of discovery}

[WASHINGTON] A Mars Sundial, about the size of a computer floppy disk, will be fixed to the Mars Surveyor 2001 lander due to touch down on the red planet in January 2002.

Viewers on Earth will be able to tell Martian time by tuning into pictures of the sundial taken by the Surveyor's panoramic camera and broadcast over the Internet.

Aside from its public relations value, the sundial will be used to calibrate the lander's colour camera. The idea came from Bill Nye, who as 'Bill Nye the Science Guy' hosts a popular children's science show on US public television.

Nye used children's design suggestions and enlisted the help of experts. These included Woodruff Sullivan, an astronomer and sundial expert at the University of Washington, and artist Jon Lomberg, who had a hand in the creation of the Voyager record sent into interstellar space with the Voyager 1 and 2 spacecraft in 1979.

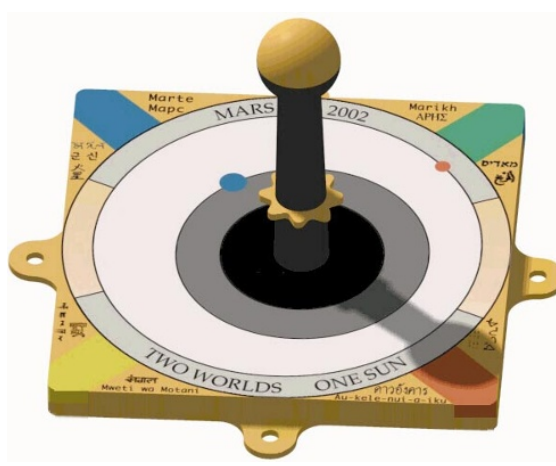

Bright idea: pictures of the Mars sundial will be broadcast over the Internet from 2002.

Around the sundial's base is engraved a Voyager-like message that reads in part: "We sent this craft in peace to learn about Mars' past and about our future. To those who visit here, we wish a safe journey and the joy of discovery." Tony Reichhardt 